\title{
THE MEXICAN COTTON BOLL WEEVIL, ANTHONOMUS GRANDIS BOHEIMAN, IN HAITI
}

By André Audant, Entomologist, and Albert OCCÉNAd, Cotton Specialist. Service National de la Production Agricole et de l'Enseignment Rural, Republique d'Haiti.

The known distribution of the Mexican cotton boll weevil, $A n$ thonomus grandis Boheman, until recently has been the southeastern United States and the cotton-growing regions of both the Pacific and Gulf coasts of Mexico, but not including the central plateau known as the Laguna district, nor the eastern and central part of Yucatan. Only a few authentic records are known of its presence in Central America. It has several times been recorded from the Island of Cuba in the West Indies, but its scarcity there is due to the fact that cotton is not a commercial crop, and even the wild cotton may at times be so completely destroyed temporarily by hurricanes that over large areas the insect may cease to exist for a series of years. In such areas, cotton is at times commercially grown without being attacked by the weevil, but, possibly due to the later appearance of this pest or more probably to economic factors and the inertia favoring other crops, has never succeded in becoming permanently established. The presence of the boll weevil is indeed mainly of importance, not in Cuba itself, but in constituting a threat to the nearest large island to the east, Hispaniola, where cotton is extensively grown and has long been one of the major exports from the Republic of Haiti. At its narrowest point, between Punta Maisí of eastern Cuba and Cap du Mole of northwestern Haiti, the Windward Passage is only fifty miles wide, but, so far as known, the boll weevil has never by its own efforts bridged this gap in sufficient numbers to become established in Haiti.

It is supposed that Anthonomus grandis was introduced by accident into Haiti, probably in the personal effects of returned emigrants from Cuba, or in commerce by boat from Texas, about 1932. It is most curious that it was found at this time near two ports, Jacmel in the south of Haiti, and Gonaives in the west, neither of which is near Cuba. The first indication of its presence was the unusual number of fallen squares noted for the crop of 1932-33 by cotton growers close to Jacmel, but the loss was not sufficiently severe to cause alarm at that time. During the season 1933-34, the infesta- 
tions had spread to the regions around Gosseline, Lafond, Meyer and Cayes-Jacmel itself, but the intensity of the infestation was so light as to attract little attention from the growers. By the end of January 1935, however, the erop was a complete loss in the Jacmel region. Typical was the loss of Monsieur Désenclos, from a normal yield of 50,000 lbs. of cotton, to a low of $300 \mathrm{lbs}$. in that year. MM. Barreau and Valvil, of Carrefour Fauché, lost their entire crop.

A general survey made at the beginning of the year 1935 showed that the weevil was close to Port-au-Prince, at Bolosse, Bourdon, etc. All the area between Port-au-Prince and Grand Goâve was infested, as well as the entire plain of Gonaives from Savanne Désolée to Ennery. Towards the end of the erop, in May and June, the dispersion had reached Petionville and the road from Frère, and in the Department of the South had reached Carrefour Desruisseaux near Miragoâne.

By June 1935, the boll weevil had become established to the north and east of Port-au-Prince, and before the end of the harvest it had reached the neighborhood of l'Arcahaie and the lower slopes of Morne á Cabrits. In the Départment du Sud, the Plaine d'Aquin became so completely infested that, altho at that time the entire region around Cayes was still not infested, for quarantine purposes it was considered so, and the restrictions, which had greatly hampered commercial traffic in and out of this region, were removed.

Up to the present time, the regions of Saint-Mare and of the Plateau Central have remained free from the pest, under the protection of a very severe quarantine. It has been found also, that in the Plaine de Cul de Sac, the trade winds blowing from Petionville and Ganthier towards the west tend to carry out to sea any weevils in flight, thus protecting, to some extent, the region to the north. But while the Plateau Central is in addition protected by zones where cotton does not grow, the Savane Diane and the Morne á Cabrits being thus in little danger of infestation by natural spread of the weevil, there are many chances that the region of Saint-Mare will become infested in the near future because of the great amount of traffic between l'Arcahaie and Saint-Mare. Its natural spread would otherwise be hindered by the relatively arid zone of Magazins Carriès.

If the region of Saint-Marc, as is to be feared, becomes infested this year, a special watch should be kept to retard the entrance of: 
the weevil into the Plateau by the Vallee de l'Artibonite (Les Verrettes, la Chapelle and Mirebelais).

\section{EXTENT OF LOSSES}

The records kept at the port of Jacmel facilitate a study of the losses suffered since the appearance of the boll weevil, as only the cotton grown in the immediate vicinity of Jacmel is exported from this port, and the region is entirely infested except at Cotes de Fer, of which the production is divided between Cayes, Petit Goâve and Jacmel.

Table No. 1

EXPORTATION OF COTTON FROM JACMEL, 1924 TO 1936 Kilos

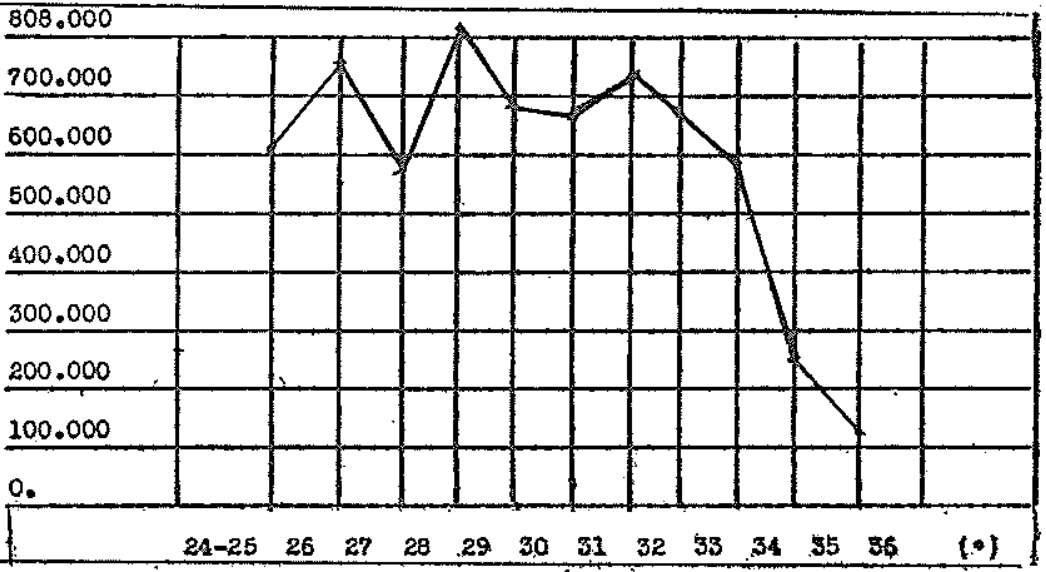

(*) From O(tober to June $30,1936$.

Before the appearance of the boll weevil, the average exportation of cotton from Jaemel was $639,469 \mathrm{kgr}$., the average of nine years. Becanse of the efforts of the Service Technique de l'Agrieulture, and due to the encouragement of a good price, in 1931-32 the production increased to $740,890 \mathrm{kgrs}$., and in 1932-33 (the year in which the weevil is supposed to have been introduced, but berore it had begun to attract attention or do much damage) the production was still above the average, or 670,013 kgrs. By 1933-34, this had decreased to 481,091 kgrs., in $1934-35$ to 238,074 kgrs. In $1935-36$, the produetion has again been halved, to 116,381 kigr's.

Considering 0.15 gourdes ( $\$ .03$ in U. S. Currency) as the minimum price per pound of raw cotton, and taking the nine year aver- 
age as the normal production from Jacmel $(639,469 \mathrm{kgrs} .=4,000,000$ pounds), the losses may be listed as follows:

1933-34-1,100,000 lbs. of raw cotton, valued at

$1934-35-2,500,000 \mathrm{lbs}$. of raw cotton, valued at

165,000 gdes.

1935-36-3,200,000 lbs. of raw cotton, valued at 375,000 gdes, 480, 000 gdes.

1, 020, 000 gdes.

This is an average of more than 300,000 gdes. ( $\$ 60,000$ in U. S. currency) a year lost by the cotton growers of the region of Jacmel, without taking into consideration the losses of the exporters and all others interested in the cotton trade at this port.

The records available for Gonaives do not show so clearly the extent of the damage caused by the boll weevil around this port because it also exports a large part of the cotton from the Plateau Central, where the area planted has greatly increased in recent years.

Table No. 2

EXPORTATION OF COTTON FROM GONAIVES, 1924 TO 1936 Kilos

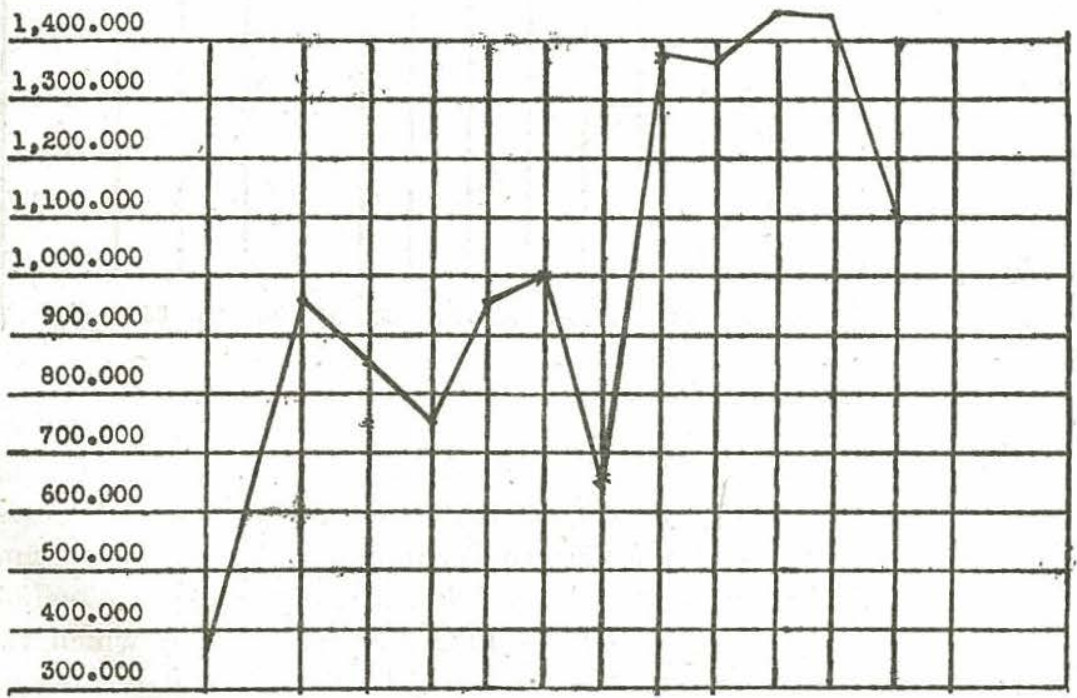

$24-25$ 26 $27 \quad 28 \quad 29 \quad 50 \quad 31 \quad 32 \quad 33,34 \quad 35 \quad 36$

(*) From October to June 30, 1936.

Nevertheless, the above curve shows that, in spite of the great impulse recently given to the growing of cotton, production has remained stationary, even slightly decreasing in 1934-35. The de- 
erease in production seems likely to become more significant this year, since from October to June, 1936, the exportation has been only 1,136,069 kgrs., while during the same period last year 1,392,810 kgrs. had been exported, a decrease of about 9 per cent.

This year, for the period October to June, Port-au-Prince and even Saint-Mare show similar decreases in production:

\begin{tabular}{|c|c|c|}
\hline- & Saint-Mare & Port-au-Prince \\
\hline 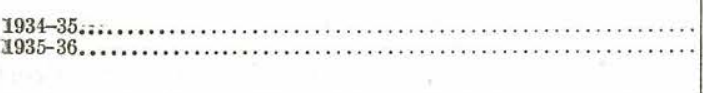 & $\begin{array}{l}2,350,778 \mathrm{kgrs} \ldots \\
2,116,144 \mathrm{kgrs} . . . \\
\text { A decrease of } 9 \%\end{array}$ & $\begin{array}{l}1,603,112 \text { kgrs. } \\
1,487,255 \text { kgrs. } \\
\text { A decrease of } 9 \%\end{array}$ \\
\hline
\end{tabular}

Such is the present situation, with little promise for the future. It is certain that as long as the entrance of the boll weevil into the region of l'Artibonite and the Plateau Central can be retarded, and especially if at the same time the area planted to cotton in that region is increased, the effect of the boll weevil on total production of Haiti will not at once be noticeable. But if Saint-Marc, which exports 40 per cent of the total production of the Republic, and the Plateau Central, whose production is 20 per cent of the total crop, become infested to the same extent as Jacmel the total production of the Republic will be sharply and permanently decreased. It is absolutely certain that the boll weevil is not a temporary pest, which we can hope to get rid of in the future. It will be impossible to eradicate the weevil now that it is so firmly established here. The problem is not how to get rid of the boll weevil, but how we can maintain cotton production despite its presence.

The question is at once raised whether it is possible to maintain cotton production at the present level with the native perennial type of cotton and present methods of growing the crop. Is it possible for the ordinary farmers (who produce more than three-fourths of the total crop) with their limited means, to increase the production of their farms to compensate for the destruction caused by the boll weevil? Or can the farmers be induced to increase the area devoted to the production of cotton so that from more plants they obtain the same total yield as before the appearance of the weevil? Judging by the attitude of the farmers who lost their crop last year from boll weevil, it seems most probable that very few ordinary farmers will either have the means to increase the yield or feel sufficient incentive to increase the area under cultivation.

Is cotton growing then to be abandoned in Haiti, and if so, what other crop can take its place? It is certain that if a crop could be found, capable of giving the same financial returns as cotton in less 
than five years, in the semi-arid soils known as "cotton soils", it would be wise to make the change. That being uncertain however, and considering the general dislike of farmers for new crops, the desirability of substituting an annual, short-season type of cotton forthe perennial type now grown has been suggested.

In its relations to the boll weevil, the Haitian type of perennial cotton has a number of disadvantages. Being a perennial type of cotton, it furnishes fresh green leaves for the nourishment of adult weevils during almost the entire year. Furthermore, its large size and abundant foliage so completely shades the ground that the immature stages of the weevil in fallen squares and bolls are not killed by the heat of the sun on the bare ground between the rows as in the case of other kinds of cotton. Altho the production of squares is largely confined to two months, yet a sufficient number of squares are produced before and after this period to furnish a much longer possible period of reproduction for the weevil than in the ease of the strains of American upland cotton especially selected for short season. An additional disadvantage, having nothing to do with the boll weevil, is its low yield, only a "millier" (one thousand pounds) of raw cotton per hectare under very good conditions.

On the other hand, the native Haitian type of perennial cotton: has certain unique advantages making it peculiarly suitable to Haitian conditions, at least up to the present. Foremost among its advantages is a resistance to the attack of the pink bollworm so marked that the commercial damage caused by this pest since its appearance in 1925 is negligible. When grown in experimental plots beside many other kinds of cotton, this resistance to pink bollworm attack is very marked, but when grown commercially in the absence of other varieties, the pink bollworm practically ceases to exist. During the beginning of the crop, rarely can more than one or two infested bolls. be found in several hour's search, and even at the very end of the picking season, infestation is normally not more than 1 or 2 per cent, too little to be noted by either grower or exporter.

The Haitian farmer is used to the perennial type of cotton. It is not necessary to plant every year, and the same plants yield for several years, even if not cut back to the ground at the end of the picking season. Practically the only expense of growing cotton in Haiti is harvesting the crop and transporting to market, making the expense of production so low that even the small return on account of inferior quality and low yield nets the farmer an excellent profit. At present, that profit seems about to be eliminated by the boll weevil, but if the parallel of the pink bollworm is any criterium, the 
appearance of this new pest may merely serve to eliminate the strains of native cotton most susceptible to its attack, just as the advent of the pink bollworm eliminated the foreign strains of Brazilian Kidney, Meade and other imported varieties mingled at that time with the Haitian perennial cotton.

\section{EXPLANATION OF MAP}

The outline map of the Republic of Haiti is taken from the "Carte publiée par les Fréres de l'Instruction Chrétienne avee approbation du Département de l'Instruction Publique par sa letter en date du 9 Octobre 1931'.

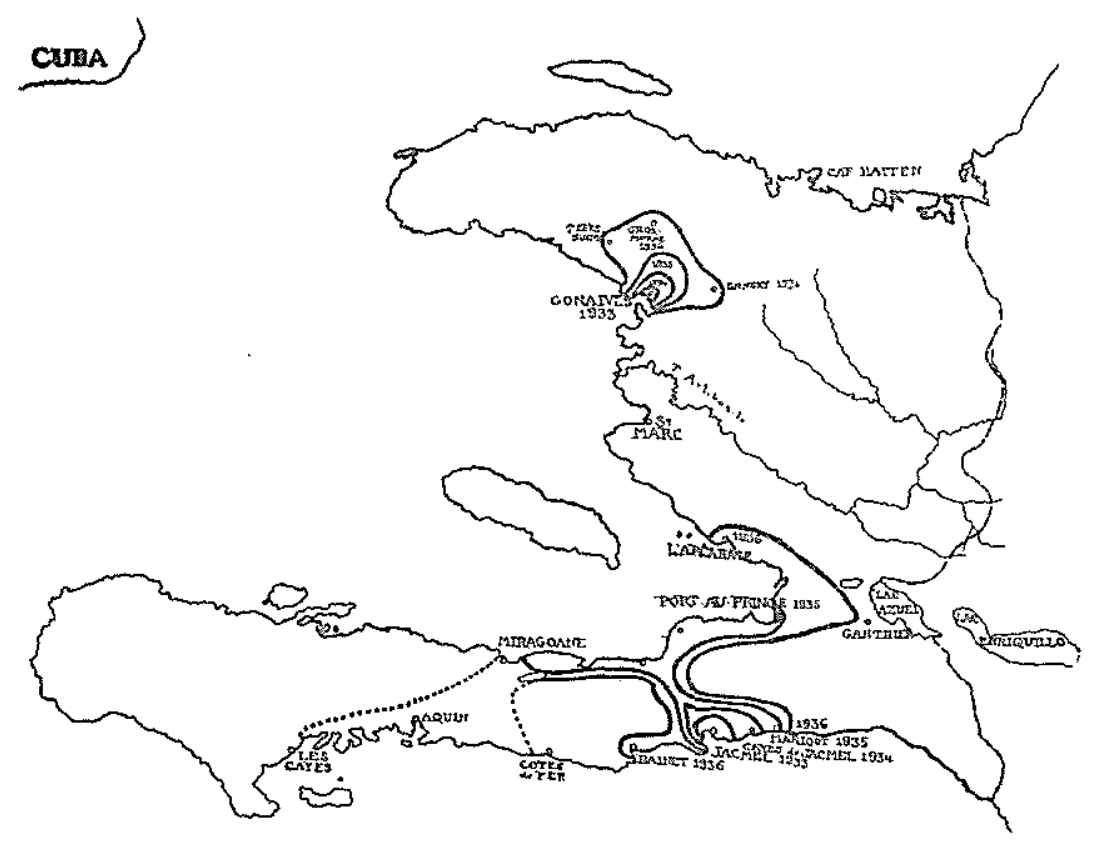

Haiti is the western part of the Island of Hispaniola, in the West Indies; the eastern part being the Republic of Santo Domingo. To the northwest is the Island of Cuba, fifty miles away; to the southwest is the Island of Jamaica, too far away to be shown.

The lines marking the dispersion of the boll weevil in Haiti were determined by the authors for the years as noted on the map itself.

The high mountain range which forms the southern peninsula of Haiti, locally "Presque Isle", is connected with the remainder of the island by the Plaine de Cul-de-Sac, only a few feet above sea leavel north of Port-au-Prince, and considerably below sea level at 
the lagoons of Lac Abuei and Lac Enriquillo. This mountain range is sufficiently broken north of Jacmel to permit passage of a road, and it is along this road that the boll weevil gained access to the northern plain of Presque Isle. After becoming established north of the mountain range, it spread east to Port-au-Prince (1935) and l'Arcahaie (1936), and to the west to Miragoane (1935) and south across the mountains along the road to Aquin and Les Cayes.

The spread of the boll weevil from Gonaives (1933) is presumably determined by the prevailing winds from the southeast, keeping it out of the Plaine de l'Artibonite, and carrying it northwest to Terre Nueve (1936), while commerce is largely responsible for its spread along ,the road east to Ennery (1936) and north to GrosMorne (1936). 